\title{
The territoriality of the network economy and urban networks: evidence from flanders
}

\author{
PETER GABUS $\uparrow$ and WIM VANHAVERBEKET\$ \\ $\dagger$ Institute for Social and Economic Geography, Catholic University of Leuven, \\ W. De Croylaan 42, 3001 Leuven, Belgium; \\ e-mail: peter.cabus@geo.kuleuven.be \\ †Department of Technology Management, Eindhoven University of \\ Technology, PO Box 513, 5600 MB Eindhoven, The Netherlands; \\ e-mail: w.p.m.vanhaverbeke@tm.tue.nl \\ $\S$ Department of Business Studies, University of Hasselt, University Campus, \\ Building D, 3590 Diepenbeek, Belgium
}

\begin{abstract}
As the network economy is continuing to develop, external economies are taking over internal economies and they are increasingly determining the entrepreneurial logic. To evaluate the territorial impact of this new logic a theoretical framework is developed based on a division of external economies between agglomeration economies that play a role in the economic functioning of urban areas and network economies that result from the networking among firms.

The general picture of firms located in Flanders is one of intense networking within agglomerations, especially in their networking with suppliers, together with intense short and long distance relationships, where urban areas dominate the scene.

A comparison between the urban networks introduced in spatial policy and the geography of firms' networks, which has been investigated in this paper as the outcome of a large scale questionnaire, reveals that the nature of the firms' networked territory can in fact not be translated in terms of urban networks but in terms of relationships between firms located in territories with dynamic industrial communities, and where cities, as a contextual place, play an important role.
\end{abstract}

Keywords: network economies; agglomeration economies; network enterprise; networked territory; polycentric urban networks.

\section{Introduction}

The concept of networking, as a way of explaining the functioning of society, is getting more popular in several disciplines. In this respect the work of Manuel Castells (1996), The Rise of the Network Society, has to be considered as a trendsetter. Although economic processes are not the only basis for Castells' conceptual framework, they certainly constitute an important dimension of it. The developing network economy and the resulting network enterprises are the first theme that will be explored in this section.

The network economy has also quickly found its way into policy-making, especially in the field of urban, regional and physical planning at the European level and in individual European countries (Ministry of the Flemish Community 1997, European Commission 1999). Consequently, the urban network concept is the second theme to be explored. 
Although the combination of these two themes seems to be obvious and is also presented in this way (Albrechts et al. 2003, Albrechts and Lievois 2004, VROM 2004), we argue that this apparently consistent logic has to be examined in a critical way. To understand the logic behind the network enterprise we therefore raise a number of research questions that deal with the geography of this logic and the viability of polycentric urban structures as a concept to understand this logic.

\subsection{Network economy and network enterprise}

Networking between economic agents is still increasing rapidly. Indeed, to stay competitive, companies had to change their organization and inter-firm relationships to a considerable degree over the last 25 years. New forms of corporate organizations and new co-operative strategies between producers, suppliers and clients have replaced Fordist hierarchical structures. In these new industrial relationships flexibility of production and labour become the focal point of attention. In this process towards flexibility internal economies of scale are replaced by a system in which external economies and economies of scope are predominant. This system is characterized by a progressive externalization of the production structure, giving rise to a production chain functioning as a networked enterprise (Hinterhuber and Levin 1994, Miles and Snow 1995, Castells 1996, Morgan 1997). For Castells (1996: 171), the network enterprise is a new organizational paradigm and he defines it as 'That specific form of enterprise whose system of means is constituted by the intersection of segments of autonomous systems of goals'.

Together with the process of externalization - that, of course, is only playing within existing firms - new firms will focus much quicker on their core competence as a result of the fierce competition. In these systems of inter-firm networking, big companies as well as SMEs are actively combined in the value chain (Storper 1999) and jointly they are reconfiguring business systems (Normann 2001). The external corporate organization - the network organization - becomes a determining part in the competitive position of the firms involved.

As a result, the production process has obviously evolved towards a more complex system. Resources are replaced by a network of industrial suppliers and business services. Capital becomes increasingly global while labour remains to a great extent local. The territoriality of the network enterprise is thus playing on different geographical scales.

Of course, the logic behind a network does not always result in the same type of network. What network type is emerging depends on specific factors, such as the type of activity, the political-economic environment and the degree of competition. Thus networking offers a hybrid model of competition and co-operation (sometimes named 'co-opetition') in search for greater flexibility, sharing costs and risks, etc. (Cabus and Hess 2000).

\subsection{Polycentrism: the urban network concept}

In the context of existing polycentric urban structures in Europe, the urban network concept is gaining importance in urban, regional and physical planning (Ministry of the Flemish Community 1997, European Commission 1999, 
Richardson and Jensen 2000, Kloosterman and Musterd 2001, VROM 2004). In contrast to monocentric developments around Europe's global cities, London and Paris, the close geographical position of middle-sized urban regions is typical for urban North-Western Europe. In most cases urban networks are defined within nations or regions, such as the Randstad in the Netherlands and the Ruhr area in the west of Germany. Also cross-border networks are defined such as the Maastricht (The Netherlands)-Aachen (Germany), Hasselt-Liège (Belgium)-network and the Lille (France)-Kortrijk (Belgium) network.

Urban networks are introduced to surpass the individual capacities of the cities involved. They are introduced by several (regional) governments as a potential answer to the global economic and territorial competition and, as a consequence, they become an essential part of national or regional spatial policy-making. These polycentric urban networks are supposed to compete with other and with the bigger monocentric (London, Paris) urban regions.

The internal structure of the polycentric urban network is perceived as a complementary urban system; a division of tasks between the members of the urban network and co-operation (VROM 2001: 32) based on existing intercity relationships or on a deliberate policy of division of resources between the cities concerned. The last aspect is seen as a more efficient use of limited resources (e.g. economic and cultural investments, housing, infrastructure, etc.). As such this urban system policy may lead to a programme of co-operation between actors (public as well as private) of the cities under consideration. In this respect (inter-) urban network management is introduced too (Albrechts and Lievois 2004).

Together with urban and industrial networks (Ministry of the Flemish Community 2003) on a regional scale, in Flanders ${ }^{1}$ the 'international network' of the Flemish Diamond (Ghent, Antwerp, Leuven and Brussels - see figure 1) was introduced in physical planning in 1997 (Ministry of the Flemish Community 1997, see also Albrechts et al. 2003). These regional and international networks function as a theoretical basis for both policy goals (international competition and a complementary network with efficient use of resources) described above.

\subsection{Research questions}

Presenting the Flemish Diamond as the core economic area of Flanders/Belgium with several universities, two major harbours and the capital of Europe - all within a range of $100 \mathrm{~km}$ - is a marketing tool that has the potential to strengthen the competitive position of Flanders/Brussels as a whole, whether or not companies in the four major cities in that area are actually networking among each other. It is also beyond doubt that there exist intense relationships between the 'urban nodes' of the polycentric Flemish Diamond. Different maps indicating economic concentration, infrastructural links, traffic flows and commuting reveal that the economic heart of Flanders (and of Belgium) is situated in this urban field.

Nevertheless, there are some fundamental research questions to be raised. The first question is how the network enterprise deals with the spatial configuration in order to keep the system economically and geographically running; what is the logic behind it and what type of geographical constellation results from the network economy? A second question is whether or not the polycentric urban network model also represents a tangible geographical part of the network economy. In other words, to what degree 


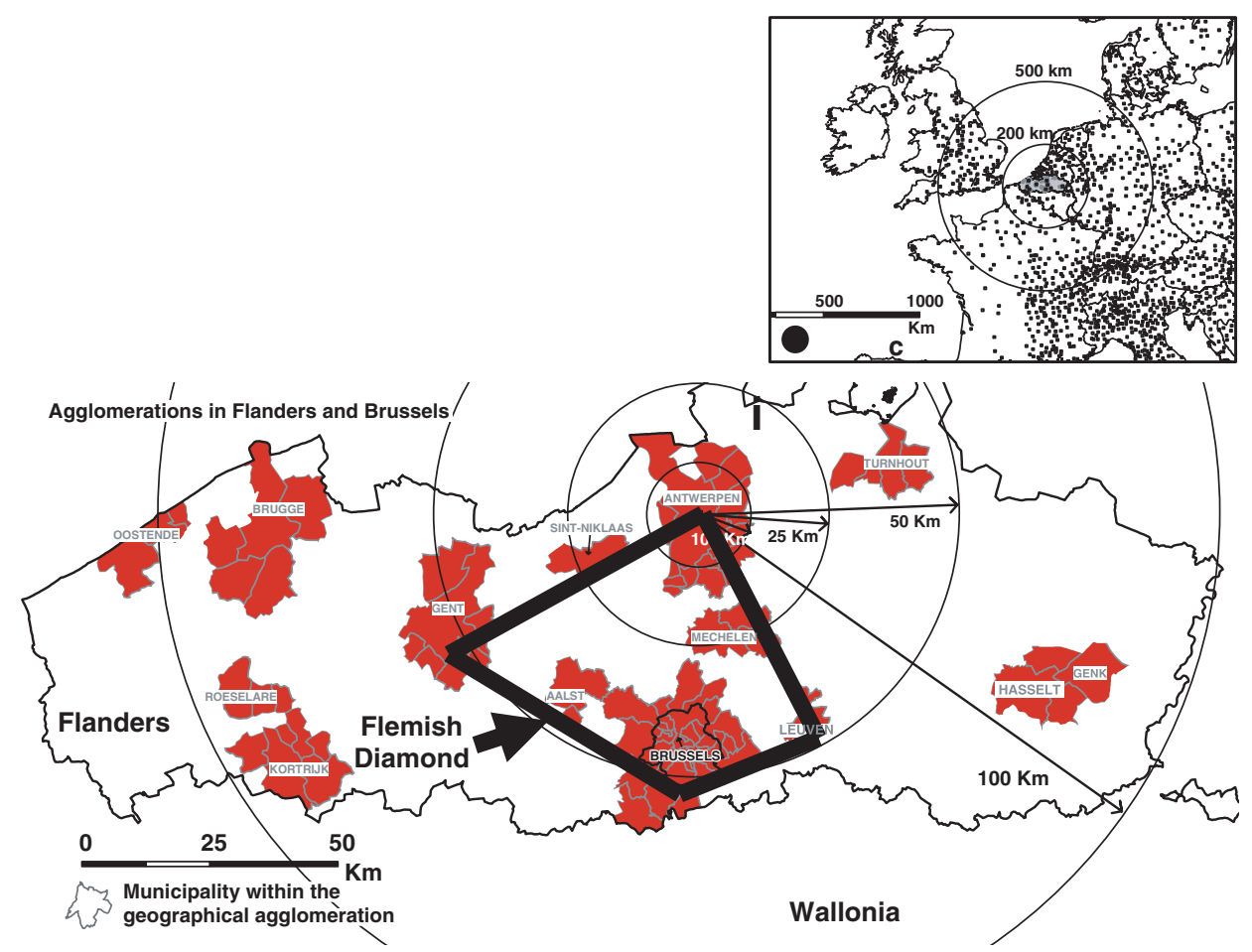

Figure 1. Geographical agglomerations in Flanders and Brussels.

Source: Own calculations; Cities in Europe: Mapinfo; Flemish Diamond (Ministry of The Flemish Community, 1997).

urban network models are also a framework for networking between economic agents (firms). A related question is how the urban network model can be the cornerstone for an economic and urban/regional policy.

To answer these research questions the paper is organized into four sections. First, the authors want to clarify the nature of external economies. Therefore we investigate the vast amount of literature that is focusing on the geographical effects of agglomeration economies. Then, starting from critiques on agglomeration theory, we propose a conceptual framework where network economies complement agglomeration economies. Finally, we argue that the interplay of both is shaping networked territories. In the next two sections we provide empirical evidence to support this conceptual framework. First, we explain the research methodology. We subsequently describe the survey conducted among firms in Flanders to investigate their network relationships, the non-response bias and the reworking process of the data. Second we picture the territoriality of the network enterprise in four topics. The first two subsections provide general information about the geographical distribution of the output of the responding firms and the overall geographical structure of their suppliers' and clients' networks. In the third subsection we test the conceptual framework focusing on the input and output relationships of firms that are based in Antwerp. These relations are analysed in terms of networked territories. These networked territories are also compared with the concept of polycentric urban networks and in particular with the Flemish Diamond. In the fourth subsection the 
authors make a coherent interpretation of the empirical findings in connection with the theoretical framework.

The last section draws some conclusions, in particular for entrepreneurs and managers. Furthermore, the authors focus on some policy implications about how urban networks can play an active role in global competition and in a more efficient use of limited resources.

\section{Conceptual framework}

As the network economy is continuing to develop external economies are taking over internal economies. Consequently, external economies are increasingly determining the entrepreneurial logic in many firms. To evaluate the territorial impact of this new logic it is necessary to divide external economies in its two major components, i.e. agglomeration economies and network economies (Cabus and Vanhaverbeke 2003b). Figure 2, which is explained in more detail in the next three sections, illustrates the logic behind this division.

\subsection{Agglomeration economies: spatialization of external economies}

\subsubsection{Basics}

The ever-increasing number of inter-firm relationships is a consequence of the growing popularity of the network enterprise. Most economic interactions - material linkages as well as information flows - are influenced by the proximity of the economic actors

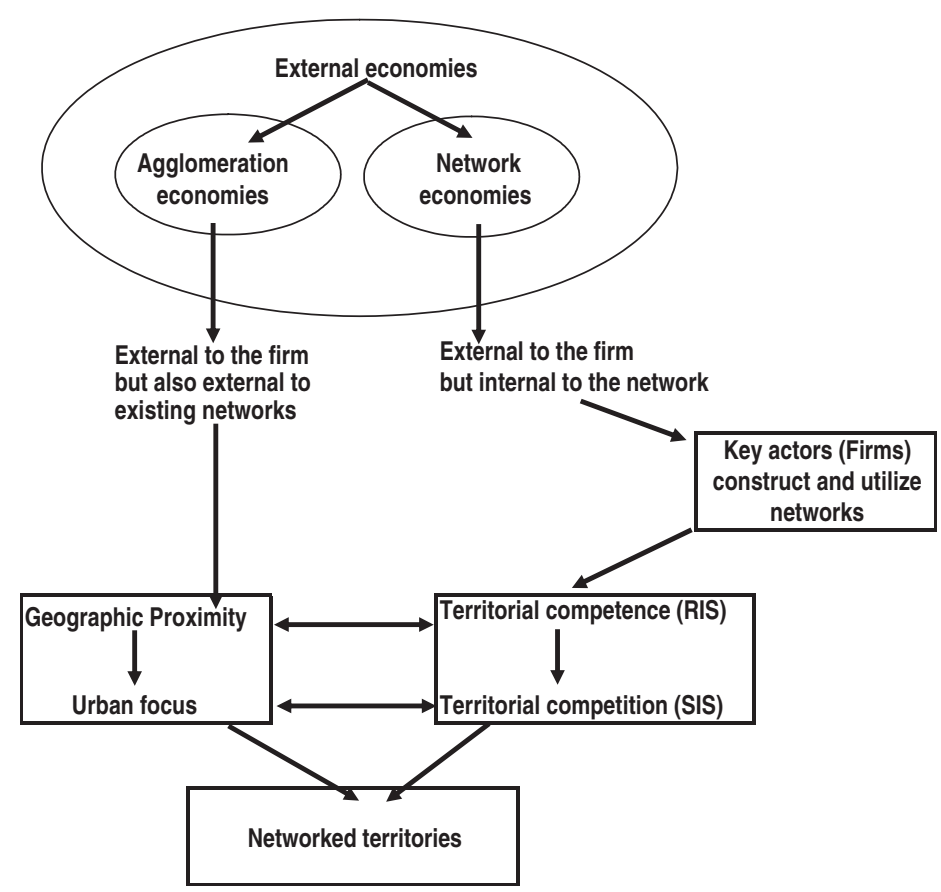

Figure 2. Conceptual framework. 
involved. In most filières ${ }^{2}$ some of the firms involved prefer to work with partners that are located in their proximity to save on transaction costs.

A vast amount of literature has been produced on agglomeration economies. This is especially the case in the last 25 years, where theories have been developed mainly within a global/local discourse, focusing on the role of the 'local' in the local economic development (Cabus 2001). This boost was encouraged by the discussion on postFordist flexible specialization (Piore and Sabel 1984), the re-emergence of regional 'marshallian' economies (Becattini 1992), the upcoming globalization and the focus on regions (Storper 1995, 1997, 1999, Ohmae 1996).

Marshal (1900) was the first to notice territorially based external economies in 'industrial districts'. He distinguished three interacting forces in the localization process (Krugman 1991, Fujita, Krugman and Venables 1999). First, a geographically concentrated industry supports specialized local providers of inputs. Next, a concentration of firms employing workers of the same type would offer labour market pooling. Third, geographic proximity would facilitate the spread of information, resulting in knowledge spill-over effects. In reducing transaction costs agglomerations are a geographic tool by which the firms achieve external economies.

Territorial clustering is not only triggered by reduced transaction costs, but also by the need to minimize uncertainty (Scott 1990). On the one hand, the fragmentation process of the production chain results in risk reduction because the number of the partners involved increases. At the same time, however, uncertainties in terms of continuity of the production process are growing. Therefore, fragmentation also may necessitate geographic proximity to overcome these uncertainties and to compensate for the loss of internal scale economies. This is especially true for just-in-time and justin-sequence delivery systems because the greater the distance the greater the risks in disrupting the production process (Reid 1995).

Agglomeration economies continue to increase until they are compensated by the negative effects of too-large agglomerations (diseconomies of agglomeration), e.g. as a result of the higher prices of real estate, the high costs of labour, etc. At that point, there will be a tendency to spread activities (Chapman and Walker 1991).

Research indicates that agglomeration economies are certainly at work in the context of business services. This type of service chooses strategic locations in the vicinity of city centres or industrial concentrations (Martinelli and Schoenberger 1991, 1992, Van Dinteren et al. 1994). Geographic proximity and the economies linked with it are necessary to sustain a vast range of highly specialized activities. However, some new elements (as compared to the explanation of Marshal) have to be taken into consideration too. First, it is the combination of national (even in federal countries such as Belgium or Germany) and specific local conditions that determines the competitive advantage of a certain geographical area. Porter (1990) argues that better communication, lower trade barriers, reduced transportation costs result in a situation in which particular locational advantages become even more important for industrial innovation. The position of a region and, as a consequence, the pace of innovation, will therefore be primarily determined by local differences in the level of knowledge and skills.

Second, face-to-face contact remains important not so much in relation to the final consumer of the service, but also on the input side (Sassen 1991, Illeris 1994). It is possible for an accountant to serve his client from a distance. However, proximity to his technical assistance (e.g. lawyers, software companies, etc.) is vital because the simultaneous presence of expertise is necessary. As these services are niche 
activities, a sufficient market potential is another key reason for their geographical concentration.

Third, the availability of telecommunication facilities can also trigger a process of intensifying concentration. It allows (global) firms to communicate from the (global) city with the affiliates elsewhere. Therefore, some cities are developing as specific central places for global clients. As a result, a new transnational geography of cities is born resulting in a world city network, where cities are the organizational hubs of globalization (Taylor 2004, 2005). Graham (1999) points to the fact that global cities dominate much broader realms of telecommunications activity than those usually addressed in the literature about global cities. Global cities also dominate phone, mobile phone, media communication and Internet use outside the corporate and financial sectors. The other side of the coin is that due to the concentration process in combination with the overall liberalization of particular utilities and services (new) peripheral spaces (even in the context of a city) and marginalized social groups lose out. Guy, Graham and Marvin (1997) indicated that this liberalization leads to uneven social and spatial development.

Next, only a dynamic industrial community based on knowledge creation (Malmberg, Sölvell and Zander 1996) can explain persisting agglomeration economies. Intense exchanges of business information, know-how and technological expertise, traded as well as untraded, are of major importance in the explanation of industrial agglomerations. These interactions between different actors (individuals and firms) generate new ideas and synergies.

Agglomeration economies do not only have an economic but also a social dimension: it is a collective process. In this respect the possibility to accumulate knowledge in a local milieu (Camagni 1995) is the driving force behind spatial clustering.

Finally, in being a social process the potential of the 'place' to create social capital becomes crucial (Hassink 1997). In the social capitalization process proximity has a physical (time geography) and above all a socio-cultural meaning. Social relationships become the central point of attention (Gordon and Murray 1998), with accent on relationships of knowledge and trust between the settled business community for specific mutual interests.

In short, there is a shift in focus from reducing transaction costs towards knowledge accumulation that is only possible within specific socio-cultural conditions (Storper 1995, 1999, Asheim 1996, 1998, 1999, Malmberg and Maskell 1997). The cluster approach of Porter (1998) is also inspired by these ideas. This debate considers acquired knowledge, skills and attitudes as an integral part of the social capital of a specific locality. In conclusion, the advantage of proximity translates itself in an agglomeration of companies and institutions linked together in a learning process. In turn this process attracts other economic activities. As it is the case with traditional agglomeration economies, these economies are internal to the agglomeration but external to the individual firm (Malmberg and Maskell 1997).

\subsubsection{Critiques}

The agglomeration theory, as it is explained thus far, stresses the importance of cities in economic life, especially in the case of business services. They become places where networks of firms that depend on the local culture are developed, where knowledge and innovation are socially capitalized and where the access to information is facilitated. The agglomeration makes the existence of very specialized services and concentration of knowledge economically possible. According to Gordon and 
McCann (2000) the change in emphasis in the literature about agglomeration economies from the reduction in transaction costs in input-output relationships towards networks embedded in social capital entails a confusion between different - in their view three - basic forms of clustering. Two of them have been developed from the (neo-)classical traditions of economics: the classic model of pure agglomeration, and the industrial complex model. The third model was developed initially outside the mainstream economics and is strongly related to the sociological perspective of the social network model.

In their study of linkage patterns and specialization in the London region, Gordon and McCann (2000) evaluate the first and the last model. ${ }^{3}$ Assessing the classic model of agglomeration, one of their findings is that firms - in contrast to neo-classical assumptions - may be unconscious of key externalities which their locality affords them, relative to other places. Next, their London research indicates that city firms value the (industry-specific) localization economies, rather than more general urbanization economies. In the evaluation of the social-network model they claim that within spatial planning this model has been largely derived from particular examples of spatial industrial clustering such as Italy's Emilio Romagna region and California's Silicon Valley. As already explained this gave rise to a vast body of literature stressing the importance of the local in the global with social capital and innovation capacity linked to it. They conclude however that the London region is likely to be a rather extreme case, but one that is of substantial importance in showing the social-network model to be by no means a pre-condition for the achievement of either flexibility (SME-flexibility was specific in the 'Third Italy': e.g. Scott 1988, Harrison 1992, DiGiovanna 1996) or the capacity to innovate.

Appold (1995) contests the self-evident character of the agglomeration theory. He specifically points to the industrial districts and the creation of geographical clusters. He argues that researchers' evidence on the effect of spatial proximity on firms is only circumstantial. If agglomeration economies play a role, firms in the agglomeration should have better financial performance than others outside the agglomeration. He challenges this assumption because firms having the same type of internal structure and organizational links with suppliers and other producers, but located outside an agglomeration, are as innovative and are as able to react properly on changing market conditions. It is straightforward that not all (rural) firms have the same attitude vis-à-vis external information, where extrovert and introvert behaviour exists (Malecki and Poehling 1999). With his model of dynamic disequilibrium, Vaessen (1993) claims however a more extrovert attitude of rural firms' managers. ${ }^{4}$ Thanks to this extrovert attitude, the initial comparative disadvantages in non-urban areas are compensated for, and even overcompensated for after a while.

Therefore, the argumentation to proof the determining influence of territorial conditions on the performance of companies (translating itself in terms of profit maximization and cost minimization) has not been bullet-proof so far.

\subsection{Network economies: external economies linked with the network}

Starting from the critiques mentioned in the previous section, one can conclude that there is considerable evidence that agglomeration theory can only partially explain the territoriality of the network enterprise. Of course, agglomerations and cities play an important role, but Holland (1976) already argued that processes that play in the 
economic space have to be approached carefully in terms of their effects on or influences by the geographical space. This is not only true for the new concept of the network enterprise, but this was already the case for more settled theories such as the growth pole theory of Perroux (1955). Therefore, starting from processes in economic space it is not sufficient to make a distinction between three basic forms of clustering as Gordon and McCann (2000) do. It is also crucial to introduce external economies linked to the network itself alongside agglomeration economies. One has to make a clear distinction between both (Suarez-Villa and Rama 1996). Both are an expression of external economies, but while agglomeration economies trigger spatial clustering, network economies are the outcome of the network itself and do not necessarily invoke spatial clustering.

As Gordon and McCann (2000) indicate, all firms located in urban regions can enjoy agglomeration economies whether or not they are functioning in a network (and whether or not external network economies are developed). Agglomeration economies at work can create a local culture making existent firms more competitive and one that is favourable for attracting new activities, whether or not they are functioning in a network. The advantages of urban agglomerations are thus external to the firms located in this agglomeration, but also - and as opposed to external network economies - to existing (networks of) firms.

Similar to agglomeration economies that have been analysed extensively, network economies also have to be assessed from different angles, i.e. economic as well as the more 'subtle' non-economic points of view are necessary to understand network economies.

There are the down-to-earth economies that force companies to focus on their core competences. Within this traditional focus, network economies are the result of competition on price and quality. A high degree of complexity (and costs related with it) of products, services or processes also leads to externalization. Although it is an apparently cost-driven process, these externalizations are not the major force driving producer services demand or new firms' birth. Beyers and Lindahl (1996) claim that there is always a combination of cost, quasi-cost and non-cost reasons. Quasi-cost considerations are related to strategy, scope and motivations that are indirectly related to the service user's desire to reduce costs, e.g. the installation of flexible production systems. Non-cost considerations have to do with the lack of in-house technical expertise and the rapid technological changes, the need for third party information, the growing complexity of management and increasing government regulation. The authors discuss them in the following paragraphs.

Within the context of this paper it is not possible to give a complete overview of all types of network economies. Therefore we focus on one of them, that is the process to acquire and integrate externally developed technological innovations.

As we mentioned before, firms may well be unconscious of key externalities that their locality offers them (urban economies), relative to other places. In analysing the geography of sourcing strategies of three manufacturing industries in Norway (food, machines and electronic and optical equipment) Rusten (2000) shows that the capacity of the firm to screen the market for business services depends on the size (small vs. big), the location (urban vs. rural) and the ownership status (foreign or not) of the firm. Also the use of professional brokers and the degree of local commitment can influence the local vs. regional or national/international radius of supply.

As it is the case in agglomeration theory, innovation is also a driving force behind network economies. While in agglomeration theory the capacity to create knowledge 
and to innovate correlates with innovative local milieux, Bunnell and Coe (2001) claim that innovation does not correlate with places but with key actors - individuals and firms - who construct and utilize the networks through which innovation is enacted. Rather than focusing on a single dominant scale - which is the case in most agglomeration theory literature (be it the global, the national or the regional/local scale) - they see cross-scalar innovation networks resulting in a combination of local and crucial extra-local exchanges with activity-related scales or territorializations. They show that individually captured tacit knowledge and socio-cultural capital that is considered to be crucial in the localization process in the agglomeration theory - is the basis for connections between locals resulting from individual mobility. These authors claim that this inter-local mobility of expertise is crucial in the global information economy and comes closer to the real process of innovation than the 'authoritarian discourse' of innovation that construct particular scales.

In evaluating Porter's cluster concept (1990), Simmie (2004) comes to the same conclusion at the level of the firm. He concludes that most innovative firms are part of an internationally distributed system of innovation. They use localities as places primarily to operate from rather than within them. There is a clear misunderstanding of the concept of innovation and knowledge itself. Simmie finds that the majority of the knowledge used by firms to produce market-leading innovations is concentrated within the firm itself. Echoing Cabus (2001), he claims that it is unlikely that the firms involved will be willing to share it with a local community because strategic knowledge is precisely the foundation of their competitive advantage. He finds that external sources for the most highly rated knowledge tend to be non-spatialized. These results are in line with recent publications about the MNE success in knowledgeintensive industries: high-tech companies have to tap in different, geographically bounded knowledge sources around the world (Doz et al. 2001).

\subsection{Networked territory}

In summarizing the arguments on agglomeration and network economies, there are four different forces at work behind the network enterprise: (1) static agglomeration economies/diseconomies based on input/output relationships; (2) new agglomeration economies in terms of trust and social capital; (3) traditional network economies between the members of the network enterprise with focus on core business and priceled outsourcing; and (4) the more 'subtle' quasi-cost and non-cost network economies. These forces shape the geography of the network enterprise.

As a result of their important activity portfolio agglomerations or urban regions are in every nation or region responsible for the largest share of the economic activities. In Flanders and Belgium (Cabus, Allaert and Vanhaverbeke 2001, Cabus and Vanhaverbeke 2004) and the Netherlands (Ministerie van Economische Zaken [MINEZ] 1999) the urbanized core of the spatial economic structure is responsible for 80 to $90 \%$ of gross domestic product. Therefore, from a statistical point of view, the members of the network enterprise are likely to be located in urban regions, which - following Vaessen (1993) - does not imply that non-urban firms are not present in this picture. A major question now is how the geography of the network enterprise matches the geography of (policy introduced) urban networks.

Although urban regions count for the most of the firms, this does not mean that firms are functioning in what one could call a 'church tower' ${ }^{5}$ economy, meaning that 
local networking within the urban region should be the only territorial expression of the network enterprise. Obviously, part of the networking will always be local, but especially in a globalizing economy, firms can easily jump from one scale (e.g. local) to another (regional, national, and international) to find the most appropriate network partners (Swyngedouw 1997, Uitermark 2002). In order to maximize network economies, jumping geographical scales becomes a major part of entrepreneurial strategies. Those strategies are driven by cost, quasi-cost and non-cost considerations. Swyngedouw and Uitermark indicate that there is also an important social dimension in this strategy described as 'scaling out', aimed at disempowering other actors who firms have to deal with (e.g. labour unions).

As shown in figure 2, the integration of network economies in the entrepreneurial strategies has a different geography than in the case of agglomeration economies. In the latter geographic proximity is a driving force, in the former territorial competence and competition are crucial factors. As a result, in the geography of places (cities) distance and time (Euclidian space) become relative. Places obtain a new identity from the social, economic and cultural networks individuals and firms are involved in (relational space) (Albrechts et al. 2003). Veltz (1992) already claimed that the 'territoire-zone', which is the traditional socio-political region, is being abandoned for a 'territoire-réseaux', a network of territories mainly determined by the actions of economical agents where cities perform the central role. It is a combination of local competence and capabilities, and economic opportunities present in other places that determine the competitive position of firms. In this respect non-local embeddedness (Markusen 1997) comes into play. This also means that 'the point of view of the region' differs from the point of view of the economic agents (e.g. enterprises) in the region (Storper and Harrison 1992).

The resulting geography, the networked territories (Cabus 1999, 2000), is completely different from an industrial district, innovative milieu or technology district (Maillat et al. 1995). The latter emphasizes the mutual relationship between industrial and innovation dynamics resulting from local networking and geographic proximity. The networked territory where scale jumping is essential cuts across different socio-political entities (nation states and regions in the case of a federal state such as Belgium). This reasoning is fully in line with the Spatial Innovation Systems (SIS) approach of Oinas and Malecki (2002). They consider SIS to be a link between National Innovation Systems (NIS) and Regional Innovation Systems (RIS), where firms and individuals are the connectors. SIS are overlapping and interlinked national, regional and sectoral systems of innovation which all are manifest in different configurations in space. Central in the SIS approach are the external relations of actors and the variability of relative weights of different places or regions. No innovation system is located in one place only. It may be local, regional or multinational, depending on the nature and size of the networks. As a result, the authors argue that it is not sufficient to focus only on particular RIS in trying to understand technological change. When firms for example move a product from R\&D into production, they shift the activities towards partners (and places) that specialize in manufacturing-based economies of scale.

The question is whether or not urban networks of adjacent large cities - as they are conceived in spatial policy - have also to be considered as a new expression of coherent geographical layers comparable with localized (innovation) districts. One might indeed claim that national (e.g. the Randstad in the Netherlands) or regional (e.g. the Flemish Diamond in Flanders) urban networks are an alternative 
for the region/nation. Using the terminology of Oinas and Malecki (2002), the regions/nations may be replaced by a set of RIS (urban regions) connected within SIS (urban networks).

Urban networks are without doubt introduced as a marketing tool to enhance the competitive position of the nation or region vis-à-vis the growing global competition. In their second role - a complementary network with efficient use of resources - the assumption of (a new type of) coherent behaviour of economic agents is an underlying hypothesis. This is especially true when it is expressed in terms of network management (Albrechts and Lievois 2004). However, Oinas and Malecki (2002) claim that the mere presence of a variety of industries in a(n) (urban) region does not reveal the basis of the relations between firms in any of those industries. The SIS approach - and in our words 'the networked territory' approach - helps to point out that diversity or specialization as food for innovation is not always locally available and thus needs to be complemented by networking to assure the access to expertise from more distant actors or places. This is also true from a competitive point of view. Houvenaghel and Vanhaverbeke (1997) found evidence that it is always a combination of local and non-local competencies that determines the competitiveness of the firms in a particular, geographically concentrated industry.

The aim of the next sections of this paper is to test the conceptual framework by analysing the actual territorial network strategies of companies that express themselves in a set of networked territories. We also confront these territories with the urban networks as they are introduced by policy-makers. Previous streams of literature indicate that firm size (Piore and Sabel 1984, Scott 1990, Becattini 1992) and industry characteristics (Sassen 1991, Illeris 1994) are contingencies that most likely influence the capacity and the necessity to jump geographical scales. We also examine these two contingencies.

\section{Methodology}

This section first deals with the research topics that were included in a survey conducted among firms located in Flanders. Next, the authors checked whether the results of the survey suffer from a non-response bias. Since we know the distribution of the population of firms that are located in Flanders across firm size categories and industries, we can easily detect under- or over-represented categories. Finally, the data derived from the survey are described briefly and the major assumptions of the reworking process are explained.

\subsection{Set up of the survey and researched issues}

A survey was conducted in 2003 among enterprises located in Flanders. The main focus of this survey was to detect the logic behind firms' location decisions and the factors that determine this decision-making process. The investigated industries are business services, construction, financial services, manufacturing, transportdistribution-logistics (TDL) and wholesale. Investigated firms had at least five employees. Applying these criteria to firms in Flanders resulted in a selection of approximately 30000 firms (independent firms as well as affiliates). A survey was sent 
to 20000 of them based on a stratified random selection procedure; 5499 of these firms responded.

Two questions in the survey allow us to provide empirical evidence for the methodological framework. First, respondents were asked to split up their total turnover over several distance zone categories to get a picture of the market range: within a radius of $15 \mathrm{~km}$, within the rest of Flanders, in Brussels, in Wallonia or abroad. Only $5 \%$ of the responding firms did not provide these data. Next, respondents were asked to provide the exact location of the three most important clients and suppliers. About $80 \%$ of the firms filled in one or more locations of their most important clients and suppliers. Data about the location of the three most important suppliers and clients are of course only a proxy of the 'complete network enterprise' but this information was easily given by the respondents and enabled us to draw the major lines of the networked territory based on a large-scale sample.

\subsection{Response and non-response}

The 5499 responding firms employed 203581 people in 2003. That results in a response rate of $18.2 \%$ (of the private firms in Flanders with at least five employees in the selected industries) and $21.8 \%$ when the respondents are weighted by their employment. Table 1 shows the industry-specific response rates.

Table 2 cross-tabulates the size of the firm, the industry and the response rate. The results indicate that the latter is larger for bigger firms $(22.8 \%)$, although small firms also responded in a satisfactory way (16.2\%). Most firm size categories have sufficiently high response rates, but financial services are under-represented in smaller size classes and business services are under-represented in the category of 50 to 200 employees. ${ }^{6}$ Two cells in table 2 are empty; therefore, we merged different size classes when an analysis required a cross-tabulation of firm size and industry.

Table 1. Response and non-response: firms and employment (\%) by industry.

\begin{tabular}{|c|c|c|c|c|c|c|}
\hline \multirow[b]{3}{*}{ Industries } & \multicolumn{2}{|c|}{ All firms $\geq 5$ employees } & \multicolumn{4}{|c|}{ Survey } \\
\hline & \multirow{2}{*}{$\frac{\text { Firms }}{\text { Number }}$} & \multirow{2}{*}{$\frac{\text { Employment }}{\text { Number }}$} & \multicolumn{2}{|r|}{ Firms } & \multicolumn{2}{|c|}{ Employment } \\
\hline & & & Number & Coverage $(\%)$ & Number & Coverage $(\%)$ \\
\hline Business services & 5404 & 192255 & 932 & 17.2 & 25218 & 13.1 \\
\hline Construction & 6083 & 95159 & 1133 & 18.6 & 22597 & 23.7 \\
\hline Financial services & 1436 & 38177 & 166 & 11.6 & 5262 & 13.8 \\
\hline Manufacturing & 8572 & 423024 & 1722 & 20.1 & 112272 & 26.5 \\
\hline TDL & 3413 & 87956 & 572 & 16.8 & 20130 & 22.9 \\
\hline Wholesale & 5341 & 98980 & 909 & 17.0 & 17358 & 17.5 \\
\hline Unknown & & & 65 & & 745 & \\
\hline Subtotal & 30249 & 935551 & 5499 & 18.2 & 203581 & 21.8 \\
\hline Other industries $>5$ employees & 19117 & 392611 & & & & \\
\hline$<5$ employees & 91901 & 163279 & & & & \\
\hline Flanders: private sector & 141267 & 1491441 & & & & \\
\hline Flanders: public sector & 9750 & 496660 & & & & \\
\hline Flanders: total & 151017 & 1988101 & & & & \\
\hline
\end{tabular}

Source: Own calculation of BCI, 2003 and Employment statistics 2002. 
Table 2. Response and non-response: firms responding (\%) by industry and firm size category.

\begin{tabular}{|c|c|c|c|c|c|c|c|}
\hline \multirow{2}{*}{$\frac{\text { Survey }}{\text { Industries }}$} & \multicolumn{5}{|c|}{ Size of the responding firm (number of employees) } & \multicolumn{2}{|c|}{ Number of firms } \\
\hline & $4-49$ & $50-200$ & $200-499$ & $500+$ & Sum & Survey & All firms \\
\hline Business services & 16.2 & 8.2 & 15.2 & 14.3 & 15.1 & 815 & 5404 \\
\hline Construction & 16.9 & 22.2 & 33.3 & 0.0 & 17.3 & 1052 & 6083 \\
\hline Financial services & 8.6 & 9.8 & 0.0 & 18.2 & 8.6 & 124 & 1436 \\
\hline Manufacturing & 17.6 & 21.5 & 24.2 & 25.4 & 18.4 & 1580 & 8572 \\
\hline TDL & 14.3 & 24.6 & 40.7 & 30.8 & 15.5 & 528 & 3413 \\
\hline Wholesale & 15.8 & 13.7 & 14.8 & 25.0 & 15.7 & 840 & 5341 \\
\hline Unknown & - & - & - & - & - & 44 & - \\
\hline Sum & 16.2 & 17.7 & 22.3 & 22.8 & 16.5 & $4983(*)$ & 30249 \\
\hline
\end{tabular}

Source: Own calculation of BCI, 2003 and Employment statistics 2002.

(*) Of the 5499 firms in the survey, 385 indicated that they had less than 5 employees, although they were entered in the central database as firms with at least 5 employees. 131 firms did not reveal the number of employees.

\subsection{Re-working the data}

Data on the geographical market range were provided by $95 \%$ of the respondents covering $96 \%$ of the sample's employment. The manufacturing industry had the best overall response $(98 \%)$ and TDL the lowest $(90 \%){ }^{7}$ There are of course also differences related to firm size, with the smallest response rate $(50 \%)$ for TDL firms over 500 employees. The survey results provide evidence about the share of output (sales) per distance category as a proportion of total output. To translate this proportion to output quantities we assumed that the firm's turnover and employment have a linear relationship. Under this assumption we calculated the share of the output (expressed in employment equivalent) to be attributed to each distance category. ${ }^{8}$ The results of this exercise are briefly described in the section on the geographical distribution of the respondents' sales (section 4.1).

About $80 \%$ of the firms filled in one or more locations of clients and suppliers. Having the location of clients and suppliers is one element of the networking. In this respect it is important to know what proportion of outputs (sales) and inputs (purchases) they are responsible for. A client (supplier) who represents $25 \%$ of the output (input) of a respondent is obviously more important than one that represents only $5 \%$.

To calculate this weight ${ }^{9}$ for the clients we assume that there is a linear relationship between distance zones figures (=answer on the first question) and the location ${ }^{10}$ of the clients (=answer on the second question). ${ }^{11}$ As not all firms provided information about their clients and only the three most important clients were mentioned, the rate of coverage drops to $51 \%$ of the output value of the investigated firms. With this rate of coverage we are, of course, not showing the complete sales network of Flemish firms, but it gives us an accurate picture of the transactions with the most important clients. Of course this rate of coverage depends on distance categories, firm size and industry characteristics.

The calculation of the client's sales value was possible because we could combine the figures of the distance zones' categories with the location of the clients. For the calculation of the supplier's output value we don't have an equivalent for the distance 
zones categories. It was nevertheless possible to calculate the weight of each supplier. ${ }^{12}$ These client and supplier data are the raw data for the results in sections 4.2 and 4.3.

\section{The territoriality of the network enterprise ${ }^{13}$}

\subsection{Geographical distribution of the output}

Tables 3 and 4 present industry and firm size-specific output figures per distance zone category. These results are also visualized in figures 3 and 4 . The results reveal that firm size and industry-specific characteristics have an impact on the results. For example, it is obvious that financial services, business services and smaller firms have the strongest local orientation, while TDL, manufacturing industries and larger firms have higher export rates.

In the next paragraphs of this section we make a more solid interpretation of these obvious features. The share of sales in particular distance zones represents a continuous but limited dependent variable for which a Tobit model is preferable because any share cannot be smaller than 0 or larger than 1: compared with OLS-regressions, Tobit ${ }^{14}$ takes account of the corner solution constraints (McDonald and Muffit 1980, Greene 2000). In commenting on this analysis we focus on firm size, foreign dependency ${ }^{15}$ and industry effects.

Table 3. Geographical distribution of the output by industry (\%).

\begin{tabular}{lcccrrr}
\hline \multicolumn{5}{c}{ Distance zones } \\
\cline { 2 - 7 } Industry & $15 \mathrm{~km}$ & Rest of Flanders & Brussels & Wallonia & Abroad & All firms \\
\hline Business services & 33.4 & 30.5 & 14.8 & 6.6 & 14.7 & 100 \\
Construction & 29.4 & 46.3 & 13.2 & 6.2 & 4.8 & 100 \\
Financial services & 36.6 & 40.7 & 5.9 & 10.2 & 6.5 & 100 \\
Manufacturing & 10.1 & 20.5 & 5.0 & 5.7 & 58.7 & 100 \\
TDL & 23.5 & 23.6 & 4.9 & 6.0 & 42.0 & 100 \\
Wholesale & 23.6 & 38.7 & 9.7 & 11.8 & 16.3 & 100 \\
All firms & 20.6 & 28.2 & 8.3 & 6.8 & 36.0 & 100 \\
\hline
\end{tabular}

Source: Own calculation of BCI, 2003 and Employment statistics 2002.

Table 4. Geographical distribution of the output and firm size (\%).

\begin{tabular}{lcccccc}
\hline \multirow{5}{*}{ Firm size } & $15 \mathrm{~km}$ & Rest of Flanders & Brussels & Wallonia & Abroad & All firms \\
\cline { 2 - 6 } & 30.6 & 35.5 & 8.9 & 7.4 & 17.6 & 100 \\
$4-49$ & 17.9 & 30.6 & 9.4 & 8.0 & 34.1 & 100 \\
$50-200$ & 11.8 & 23.0 & 10.5 & 8.3 & 46.5 & 100 \\
$200-500$ & 11.5 & 14.8 & 4.4 & 3.1 & 66.2 & 100 \\
$500+$ & 20.6 & 28.2 & 8.3 & 6.8 & 36.0 & 100 \\
All firms & & & & & & \\
\hline
\end{tabular}

Source: Own calculation of BCI, 2003 and Employment statistics 2002. 


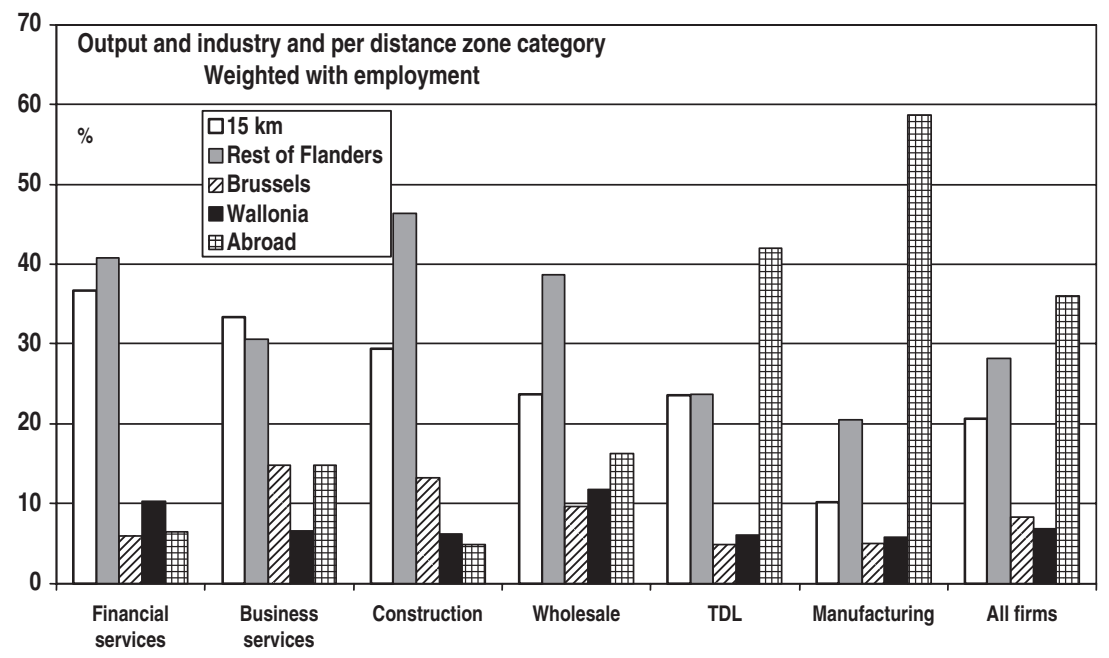

Figure 3. Output by distance zone category for different industries. Source: Own design.

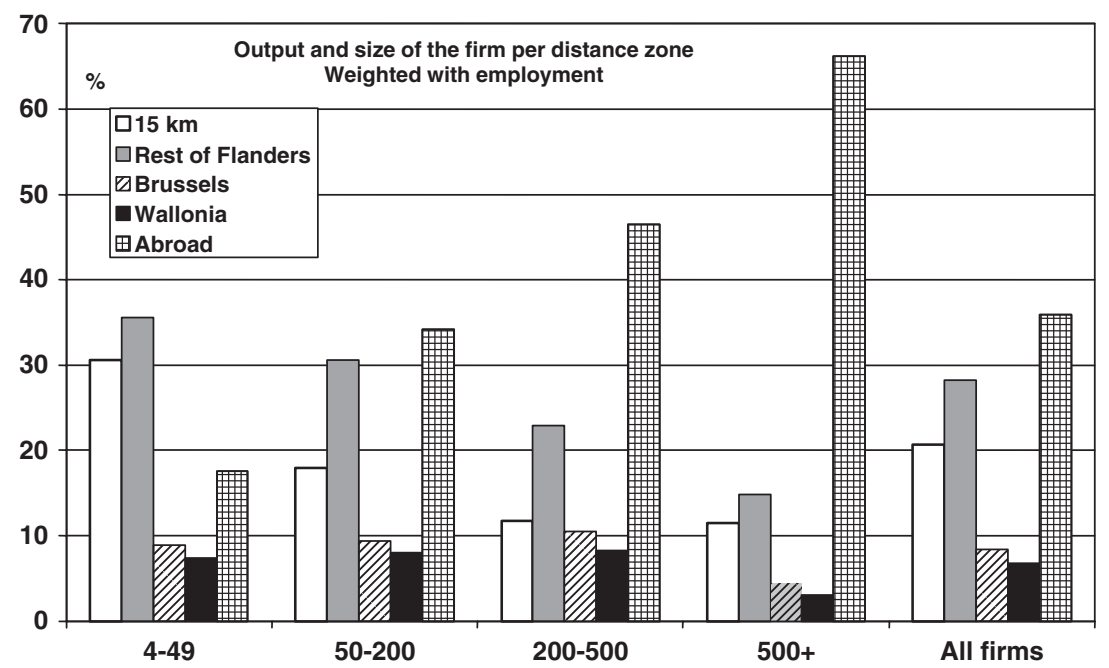

Figure 4. Output by distance zone category for different firm sizes. Source: Own design.

Larger companies tend to sell less in the immediate environment $(15 \mathrm{~km})$. The larger the company the larger is their turnover share in Flanders, Brussels, Wallonia and abroad. The larger the distance the larger the differences in market share between large and small companies. Firms that are a subsidiary of a multinational company are selling more abroad and less in Brussels and the rest of Flanders. However, on average they do not sell less in the immediate environment compared to other firms. This provides indirect evidence that subsidiaries of multinationals are located in particular places to sell to important client firms in their vicinity. 
The sector to which a company belongs also has a strong effect. The high export rate shown in figure 3 shows that the manufacturing industry in Flanders has a prominent international orientation. Business and financial services are (in comparison to the manufacturing industry) highly dependent on clients in their vicinity. This local focus supports the agglomeration theory, underlining the importance of agglomeration economies for these types of activities. These data confirm that business services are not co-locating extensively with their (industrial) clients, but with their partners or rivals in the same business because they can reap the advantages linked with the geographic concentration of central functions. However, a significant share of the transactions with clients is non-local. These findings corroborate the reasoning of Illeris (1994). Specialized services are so unique that the costs related to distance are marginal compared to the value of the service. The determining strategies behind the competitive position of these producer services are not only cost-driven. They achieve superior performance via quality and competence, creativity, their abilities to undertake research and development and their abilities to respond quickly to client needs (Lindahl and Beyers 1999). This adds other dimensions to Porter's framework of generic strategies (Porter 1990), i.e. the proximity of sophisticated and demanding customers, as one of the determinants of a competitive position, leads to an improvement of products and services. This also implies that highly competitive firms will seek out demanding customers wherever they might be located.

Construction activities are operating locally, in the rest of Flanders and in Brussels. This is an indication of a rather mobile sector covering a big part of Flanders and Brussels - its limits being determined by the maximum daily commuting distance. Except for Brussels the figures for TDL indicate a similar profile as compared to manufacturing industry. This means high export rates for both industries and relatively small output shares in other distance zones. As a supporting industry, especially for the manufacturing industry, this similar profile is not a surprise.

The output figures per distance zone for different economic activities already give an indication of the territorial characteristics of the network relationships between firms in Flanders and their clients: on the one hand agglomeration economies are at work resulting in substantial local networking. At the same time, network economies are also playing resulting in supra local and international sales.

\subsection{Geographical structure of the suppliers' and clients' network relationships}

In this section we analyse in greater detail the location and the value of the most important suppliers and clients of the responding companies. The location of one or more important clients was provided by 4356 respondents. The location of the main suppliers was provided by 4546 respondents. The responding companies listed 11092 suppliers in 1170 different locations in the world. For clients, 1294 different locations were listed with a total of 11963 clients. ${ }^{16}$

Focusing on location characteristics, we make a distinction between urban vs. non-urban locations ${ }^{17}$ of the respondents and their clients and suppliers in Belgium. Locations of clients and suppliers abroad are not specified in terms of urban or non-urban locations (section 4.3). 
(a)

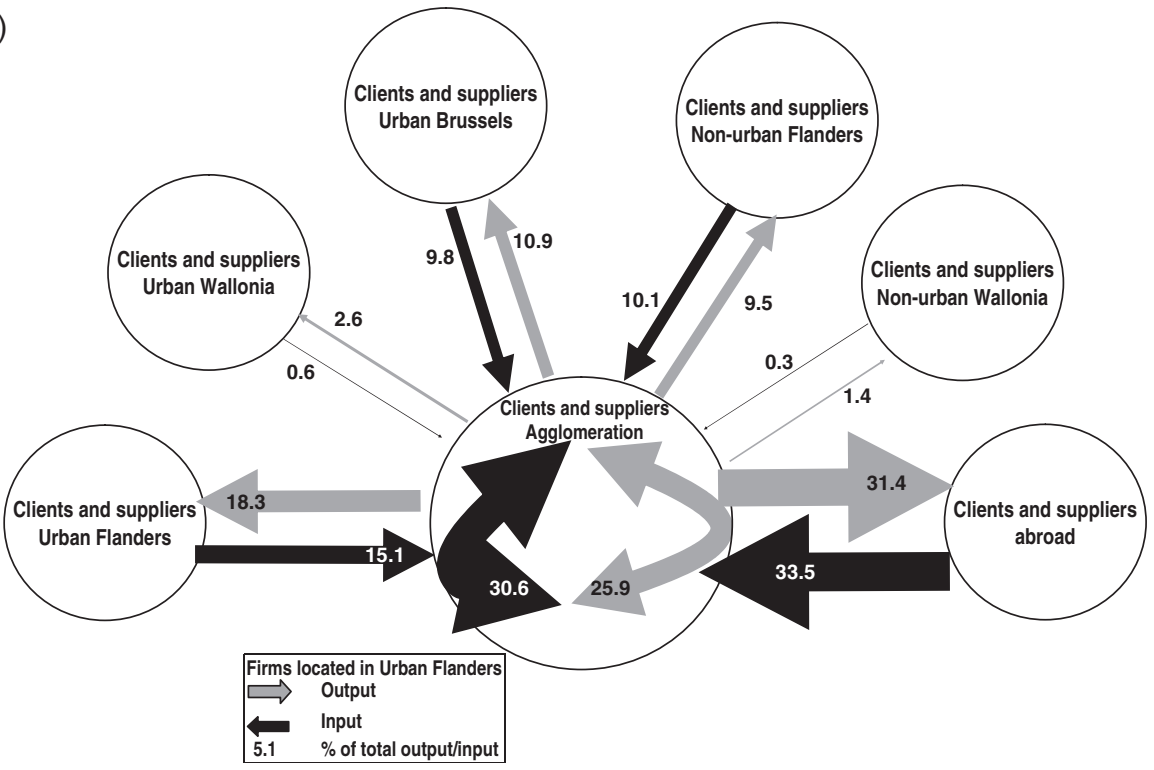

(b)

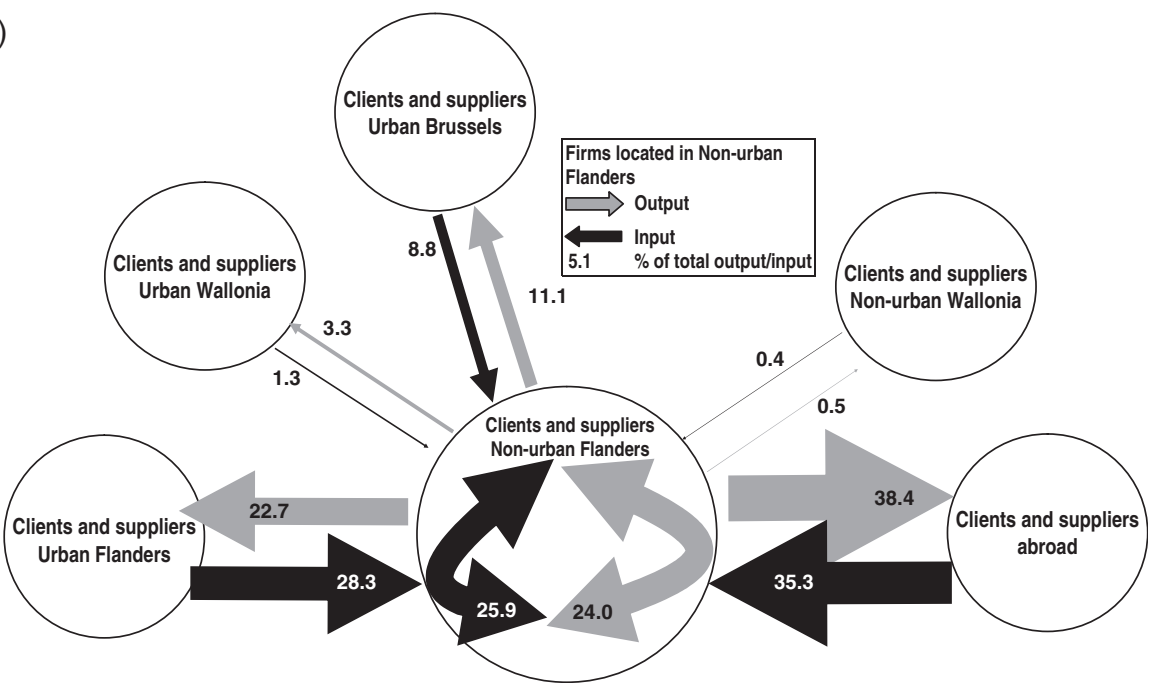

Figure 5. (a) Urban firms' relationships: all firms; (b) Non-urban firms' relationships: all firms.

Source: Own design.

Figures $5 \mathrm{a}$ and $\mathrm{b}$ give a general picture of network relationships of urban and nonurban respondents. The two schemes clarify that for urban and non-urban respondents relationships with clients and suppliers exist with particular geographical foci and intensities. When we enter into detail it is obvious that the geographical focus depends on industry and firm size characteristics.

For firms located in agglomerations (figure 5a), an important share of the sales (output) and of the purchases (input) are transactions with firms within the same 
agglomeration, or with firms in other agglomerations in Flanders. Networking with Walloon agglomerations is very weak. The reason for this weak relationship is not clear given the proximity of Flanders and Wallonia, but the language barrier (French in Wallonia vs. Dutch in Flanders) could be an explanatory factor. Another factor is probably that the economy in Wallonia had a severe shock after closing the mines in the 1960s and 1970s and the collapse of the dominant steel industry in the 1980s. Wallonia has still not recovered from these shocks. On the contrary, the economic relations with firms in Brussels ${ }^{18}$ are strong. The networking with firms located in non-urban Flanders is as strong as the relation with Brussels. Clients and suppliers abroad count for substantial shares (one-third of all relations), indicating that on the whole the international networking is more important than the intra-urban networks and the networks between urban areas in Flanders.

Focussing on the size of the agglomeration with the Tobit model, which was introduced in the previous section, we find further evidence for the agglomeration theory: the larger the urbanized region the higher the percentage of sales to customers who are located within the boundary of $15 \mathrm{~km}$. The larger agglomerations Antwerp and Ghent have relatively less clients in the rest of Flanders, but are more oriented towards Brussels. We also find that companies in large agglomerations (Antwerp, Ghent and Brussels) do not have a higher export share than those located in medium-sized cities or in non-urban areas. The percentages vary widely according to the firm-size class and the industry to which the respondent belongs. The networking of small firms differs from that of larger firms in different ways; the intra-urban sales are larger, networking with non-urban clients and suppliers is stronger, and the networking abroad is less prominent. For business services the share of intra-urban relationships is much higher. Also the networking with Brussels is stronger.

For firms located in non-urban Flanders (figure 5b), approximately one-quarter of total sales and purchases originates from transactions with clients and suppliers located in non-urban areas. The non-urban companies also have approximately the same level of transactions with firms in agglomerations. Brussels counts for the same level of relationships as for firms located in urban areas. Again, there are statistically significant differences ${ }^{19}$ between different size categories and industries. Small firms ( $<50$ employees) are networking more within Flanders and it does not matter whether clients or suppliers are located in non-urban or urban areas. Non-urban business services are networking much more with Brussels. The analysis with the Tobit model proves that the firms in non-urban areas have a weakly significant higher share of exports compared to firms that are located in large cities. Interesting to notice in this respect is that bigger non-urban firms (500+employees) have an almost complete international orientation.

In the Belgian context it is clear that agglomerations - especially in Flanders and Brussels - play an important role as economic centres in the economic networking of urban and non-urban companies. However in the whole picture of network relationships the figures point out that non-urban networking is certainly present, which can be explained with the disequilibrium theory of Vaessen (1993). Next it is clear that input and output relationships exist simultaneously at different geographical scales: the local, supra local, and international level. We will take up these general findings in more detail in the next section focusing on Antwerp, the most important agglomeration in Flanders. 


\subsection{The networked territory: input and output relationships of the Antwerp firms}

With the network relationships of firms located in the Antwerp agglomeration, we want to test the conceptual framework and to observe how the interaction between agglomeration economies and network economies shape the geography of the network economy. We also confront the networked territory constructed by the Antwerp firms with the 'Flemish Diamond', the international urban network in Flanders that is introduced in spatial policy.

The respondents located in the Antwerp agglomeration declared to have 1497 clients and 1282 suppliers; 236 clients and 322 suppliers are located abroad. ${ }^{20}$ To refine the analysis from the networked territory perspective, distance was introduced and, as we already did for the locations in Belgium, the locations abroad were qualified as urban or non-urban. ${ }^{21}$ Figure 6 gives a schematic impression of the networked territory of the input and output relationships of the firms that are located in the Antwerp agglomeration. The figure depicts these relationships for urban and non-urban locations within different radii: 50, 50-100, 100-200, 200-500 and $>500 \mathrm{~km}$. The most important urban locations are specified in the figure.

The first topic deals with the geographical scope of the network relationships. In sum figure 6 indicates that we have empirical evidence that the networked territory is playing on different geographical scales. Firms that are located in Antwerp are continuously in interaction with suppliers and clients on different geographical scales ranging from local transactions within the Antwerp agglomeration to arrangements with international clients and suppliers. The integration of different geographical levels of scale in the network enterprise is the result of the dialectic interaction between the entrepreneurial logic and territorial processes at work. In this respect there are interesting differences to note between the relations with clients and those with suppliers. Input relationships are to a larger extent of a local nature (that is intraurban or relationships under a distance of $50 \mathrm{~km}$ ). This is an indication that the supply-chain deals with uncertainty by minimizing distances. At the same time, long distance relationships $(>500 \mathrm{~km})$ account for $9 \%$ of total input. These are transactions where companies usually purchase specialized products and services where distance plays only a minor or no role.

Output relationships are much stronger for the distance range $200-500 \mathrm{~km}$, that is the range with the most important cities in (Western-)Europe (e.g. London and Paris). These findings suggest that Antwerp firms developed niche activities that are integrated in the global city networks. This profile undoubtedly fits a city with an important harbour, where international as well as local networks support this bridgehead in a northwest European context. The high intra-urban share of relations with suppliers in TDL $(+50 \%$ of total relationships) confirms this image.

Elaborating further on the role of urban vs. non-urban locations of clients and suppliers, it is clear that urban areas play a major role. Of all traceable relationships outside the Antwerp agglomeration, three-quarters of all relationships are with firms in urban areas. Not surprisingly, these figures are much higher for business services (91\% of sales and $83 \%$ of purchases) and financial services $(72 \%$ of sales and $100 \%$ of purchases), but also for TDL (92\% of sales and $67 \%$ of purchases). The economic relations of the manufacturing industry are not that strictly linked to urban areas, although urban clients and suppliers are still responsible for $70 \%$ of the transactions. There is also a strong positive correlation between the 'urban degree' of the relationships and the average distance between firms and their economic partners. 


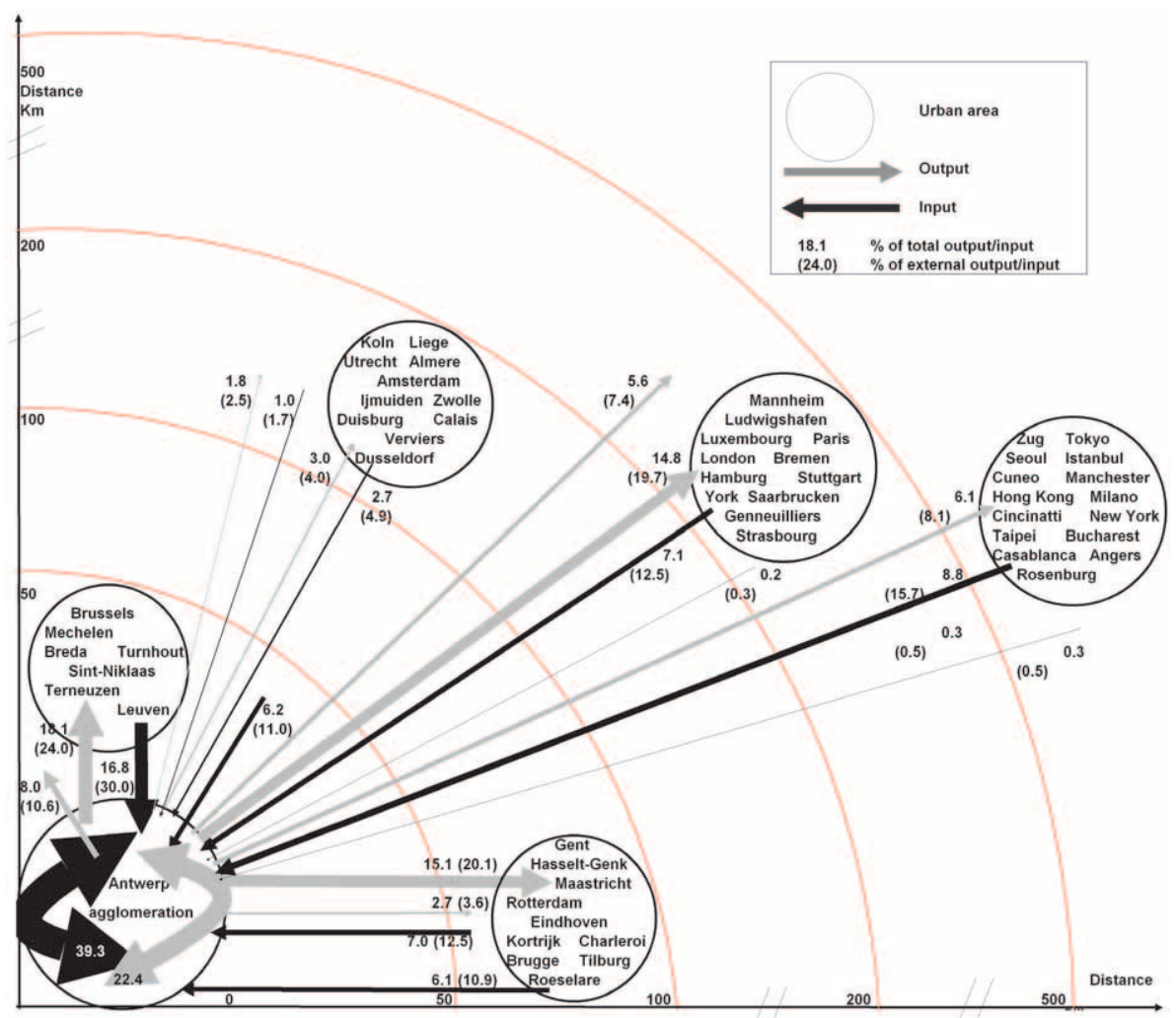

Figure 6. Antwerp firms' networked territory (all firms).

Note: The figures without brackets represent the percentage of total input/output, including the relationships within the Antwerp agglomeration. For $2.4 \%$ of total output and $4.5 \%$ of total input it was not possible to trace the exact location. We know however that these locations are situated abroad. The figures, the unknown locations abroad inclusive sum upto $100 \%$ for input and output separately.

The figures between brackets represent the percentage of the traceable input/output relationships beyond the Antwerp agglomeration. The figures sum upto $100 \%$ for input and output separately.

Almost all economic transactions over a distance of $500 \mathrm{~km}$ are transactions with suppliers and clients that are located in urban areas. In sum, urban areas dominate the picture especially for long distance relations.

A final topic is how the networked territory of firms located in Antwerp relates to the policy of urban networks. As explained in the Introduction, urban networks are introduced to enhance the competitive position of the nation (and in our case the region of Flanders). The Flemish Diamond, with Antwerp, Leuven, Brussels and Ghent as the cornerstones (figure 1) is assigned and marketed as an international urban network. Being the economic heart of Belgium (and Flanders) it is a clever move to put the Diamond on the international map and to promote it actively to attract investments in a competitive and globalizing world. Is it, however, relevant as a geographical framework for the networked territory of firms in the Antwerp agglomeration? 
Table 5. Network relationships in and outside the Flemish Diamond (\%).

\begin{tabular}{lrrr}
\hline & Output & Input & Sum \\
\hline Flemish Diamond & & & \\
$\quad$ Aalst & 0.4 & 0.0 & 0.2 \\
Brussel & 12.0 & 18.4 & 14.8 \\
Gent & 9.5 & 3.3 & 6.8 \\
Leuven & 1.2 & 0.2 & 0.8 \\
Mechelen & 1.7 & 2.2 & 1.9 \\
Sint-Niklaas & 0.4 & 1.8 & 1.0 \\
Non-urban & 4.6 & 6.8 & 5.6 \\
Sub-total & 29.8 & 32.8 & 31.1 \\
Outside Flemish Diamond & & & \\
Urban & 52.2 & 42.8 & 48.2 \\
Non-urban & 15.7 & 17.2 & 16.3 \\
NN & 2.3 & 7.2 & 4.4 \\
Subtotal & 70.2 & 67.2 & 68.9 \\
Total excl Antwerp & 100 & 100 & 100 \\
\hline
\end{tabular}

Source: Own calculation of BCI, 2003.

In table 5 we focus on the relationships of firms that are located in Antwerp with suppliers and clients outside the Antwerp agglomeration. The networked territory of the Antwerp firms spans parts of the Flemish Diamond, especially the agglomerations of Brussels and Ghent. The area covering the Flemish Diamond is responsible for approximately one-third of all the economic relationships outside the Antwerp agglomeration. The other two- thirds of the relationships go beyond the 'Flemish Diamond'. Of course, the shape and the scale of the networked territory vary with the firm's size and industry in which it is active. However, the general picture is one of intense local networking (Antwerp agglomeration) especially from the suppliers' point of view, together with intense short and long distance relationships, where urban areas (but not necessarily urban networks in the immediate proximity) dominate the scene.

\subsection{Agglomeration and network economies and polycentric urban networks}

The networked territory that has been described results from the interplay of agglomeration economies having an impact in urban areas and network economies that are playing in the network of economic relations. We know that this exercise has its limitations. First we cannot measure directly the influence of the cost, quasi-cost and the non-cost drivers as has been suggested by Beyers and Lindahl (1996). In a similar vein, we cannot trace the exact role of key actors (Bunnell and Coe 2001). Finally client and supplier relationships are also influenced by corporate geographies (i.e. ownership structures), but we don't have data in the survey to support this. In previous research in the automobile industry in Belgium (Cabus 2000), we found indeed a link between ownership and geographical patterns of suppliers, especially for industrial supply and for specialized services. Furthermore affiliates of big (multinational) firms that are specialized in specific (industrial as well as services) activities are suppliers for other parts of the company. Of course this corporate geography will influence the shape of the networked territory. 
However, within the limits of this paper, we can measure indirectly the balance between the agglomeration economies as a result of geographical proximity in the focal urban community (in our case Antwerp) and network economies as a result of territorial competence and competition. The integration of network economies into the entrepreneurial strategy explains why firms operate from localities (Simmie 2004) and tap into different resources elsewhere (Doz et al. 2001). Also the reach of the scale jumping (Swyngedouw 1997, Uitermark 2002) within the networked territory, the resulting cross-scalar networks (Bunnell and Coe 2001) and the intensity of the resulting relational space (Albrechts et al. 2003) have been illustrated for the firms located in the Antwerp agglomeration.

The fact that most relations are established with firms in urbanized regions indicates that important urban regions can indeed be considered as Regional Innovation Systems (RIS). The intensity of the connecting lines between different levels of scale indicate that Spatial Innovation Systems (SIS) were firms and individuals are the connectors, are indeed linking up (actors in) urban regions. The high degree of relationships outside the Flemish Diamond proves however that firms are not operating in a territory that coincides with the predefined framework of existing territorial administrative structures or politically constructed urban networks. The actual networked territory of firms cannot be explained by urban networks. The networked territory can only be defined in terms of relationships between firms located in territories with dynamic industrial communities (Malmberg, Sölvell and Zander 1996), where specific skills are present and competence is historically built up and maintained, and where cities, as a contextual place (Harvey 1973, Aase 1994), play an important role. This context is in most cases specific and therefore not easily transferable.

Finally, we find, in contrast with Oinas and Malecki (2002) that the presence of a variety of industries in an urban region is a basis of the relations between firms. This is especially relevant for the supplier relations.

\section{Conclusions}

In explaining the geographical effects of external economies, we argued that there are two complementary components. First, there are agglomeration economies fuelled by geographic proximity. Next, there are network economies, as a manifestation of external economies linked with the network itself and nourished by territorial competition and competencies. The combination of both translates itself geographically in a set of networked territories. The analysis of the networking between firms located in Flanders and their clients and suppliers, gives some empirical evidence on the existence and structure of networked territories.

In testing the conceptual framework with the actual network relationships of firms located in the Antwerp agglomeration, the interplay between agglomeration and network economies was clarified. There is - of course differing with firm size and industry characteristics - an intense local networking within the Antwerp agglomeration especially with suppliers, indicating agglomeration economies at work. At the same time there are intense short and long distance relationships outside the agglomeration, expressing the integration of network economies in the entrepreneurial strategy. The larger the distance the more urban areas dominate the scene. In short, the integration of different geographical levels of scale in the network enterprise is the result of the dialectic interaction between the entrepreneurial logic of networking 
firms and local territorial processes. With these findings, we support the hypothesis that important urban regions can be considered as RIS and that SIS, where firms and individuals are the connectors, are indeed linking up (actors in) urban regions.

What are the conclusions for entrepreneurs and managers? Perhaps unconscious of key externalities, entrepreneurs and managers integrate agglomeration and network economies in their network strategy. The survey results indicate that there is always a combination of local and more distant expertise in constructing networks. Local networking, especially for the supplier relationships, is already developed to a high degree. This is certainly a territorial strategy to deal with growing uncertainties due to the fragmentation of the production process and to maximize the advantages of integration in the RIS. It is however the combination of local and more distant expertise that enhances the competitive position of the firm. The overall internationalization of economy forces entrepreneurs to actively deal with these key externalities and to jump scales when necessary to stay competitive. This is especially true for smaller firms. They are much more oriented towards a local network of suppliers and clients and do not balance it with ties on a larger distance at the same level as bigger firms do. Therefore, (smaller) firms should be more actively engaged in international networks. Our policy recommendation here is to enhance the competitive position of (smaller) firms by giving them incentives to integrate them in international networks.

What about spatial (-economic) policy and polycentric urban networks? Urban networks can enhance the competitive position of a region by putting them together on the global map. Even network management as introduced by Albrechts and Lievois (2004) is certainly recommendable, especially when this is translated into urban policies aiming at a fair distribution of welfare and a more efficient use of limited resources. However, firms are not networking in predefined urban networks. In fact, it would be a surprising result that in a globalizing economy firms fold their network back to newly constructed coherent spatial entities such as spatial policy urban networks. Since the firms' competitive position is a result of their integration in international networks it is necessary to tap in different knowledge sources around the world that is contextual in many cases and therefore not easy transferable. Consequently, urban networks, as they are currently conceived by policy makers, are not an appropriate framework to understand and influence the network economy. The authors claim that these urban networks should be seen as a part of the broader framework of the networked territory, where scale jumping is essential. Of course, Flanders could be an exceptional case and we have to be careful about the possibility of generalizing our findings. On the other hand polycentrism and the installation of urban networks as a policy instrument are not unique for Belgium or Flanders. Polycentrism is a common characteristic of a large part of north-western Europe. It is appropriate to assume that firms elsewhere in Europe have similar considerations in dealing with the spatial configuration in order to keep the company economically and geographically running.

\section{Notes}

1. Flanders is a state of federal Belgium and has a population of approximately 6 million inhabitants living in an area of $13500 \mathrm{~km}^{2}$. With its 435 inhabitants per $\mathrm{km}^{2}$, it is a high-density populated area. Within Belgium, Flanders accounts for $60.4 \%$ of the gross domestic product and more than $70 \%$ of total Belgian exports. As a result, it is the dominant economic region within Belgium. 
Brussels accounts for $14.2 \%$ and the Walloon provinces for the remaining $25.4 \%$. These characteristics result in an intensively used space and important urbanized areas. Physical planning and regional economic policy belong to the competences of the region.

2. A filière is the whole of mutual interdependent activities, each of which is responsible for a certain phase in the production process.

3. The industrial complex model is indeed specific and based on trading links governing their locational behaviour. It is in most cases sector-specific and linked with transaction costs that in nineteenth century literature were assumed to be solely transportation cost (Weber 1909) (e.g. clusters of oil refining, chemicals, iron and steel, e.g. Chardonnet, 1962, 1965 - and to a certain degree also the automotive industry - e.g. Toyota city).

4. In fact, the non-urban location requires an adjusted management in a context of locational disadvantages. His research indicates that the management of non-urban firms have to develop from the start a proper strategy to overcome their locational disadvantages. Urban firms don't have to do this and in the end the non-urban firm will perform better than their urban peers.

5. This is a typical expression in Flanders to indicate that one has a geographical action space not reaching further than the direct environment.

6. We compared the sample and population with respect to their distribution across industries. The Chi-squared test was significant, both for the number of firms and their employment level. The value and statistical significance level of Chi-squared depends on the number of observations. Since the size of the sample is exceptionally large each small deviation from the distribution of the population resulted in significant tests. Therefore, we calculated Cramer's coefficient as a measures of association. The values for this measure range from 0 (no associations between columns and rows) to 1. Comparing the population and sample leads to a value of 0.04 in case we weight with the number of firms and 0.10 in case we use employment as weight factor. Although this test is again significant (because of the large sample size) the values for the Cramer coefficient are small. This is reflected by the small differences between sample and population in the distribution across industries.

Although the differences between the sample and the case are small, we adjusted the weight of each category in order to get results based on a sampling that reflects the firm size and industry distribution of the Flemish firm population.

7. The authors compared the total sample of respondents with the sample of the companies that have answered the question about the market range of clients. The distribution across firm size catageories is very similar for both samples. Those companies that answered this question about the market range were slightly under-represented in the category of 50-1999 employees and large companies were slightly under-represented. The differences are small: Cramer's coefficient is smaller than 0.01 both when number of firms or their employment is taken as the basis for the calculation.

The distribution across industries generates similar results. Companies that answered the 'range' questions represented almost always the total sample of respondents. Cramer's coefficient is 0.008 when calculations are based on the number of firms and 0.016 when employment is taken as a weight factor. We can conclude that the sample of firms that answered the 'range' case are representative for the whole sample of respondents.

Although the differences between the sample and the case are small, we adjusted the weight of each category in order to get results based on a sampling that reflects the firm size and industry distribution of the Flemish firm population.

8. If a firm has, for example, 100 employees and, for example, $50 \%$ of the output is sold within a radius of $15 \mathrm{~km}$, one may reasonably assume that 50 employees are needed to produce this part of the output.

9. We did not take the risk of asking for the share of a customer in the firm's sales (output) or the share of a supplier in the firm's purchases. This is sensitive information and we feared that the response rate would drop considerably.

10. The location is that of the municipality where the client/supplier is located. Based on the geographical coordinates it was possible to calculate the distance from the firm.

11. When, for example, one or more clients are located within a distance of $15 \mathrm{~km}$ of the firm, we assume that the output of the investigated firm for this distance category can be assigned to these client $(\mathrm{s})$.

12. To calculate the suppliers' input value, in a first step we assigned the employment of the respondent to the suppliers that are mentioned by the respondent. When a firm has, for example, 100 employees and 2 suppliers are mentioned, each of them has an equivalent of 50 employees. This exercise results in an input equivalent to $70.5 \%$ of the employees in the investigated firms. From the exercise with the clients we know that this is an overestimation that varies with distance, industry and firm size. Indeed when we should not have the data by distance zone categories, the same exercise for the clients would result in an output equivalent of $70.4 \%$ of the employees in the investigated firms (instead of the calculated $51 \%)$. It is established that the percentage of the input equivalent $(70.5 \%)$ is virtually the same as the one for the output equivalent $(70.4 \%)$. Also one can assume that the rate of coverage per distance zone category for clients and suppliers will not differ. Therefore we correct the input figures for the suppliers with the rates of coverage per distance zone category as they are established for the clients.

13. As explained in footnotes 6 and 7, although the differences between the sample and the case are small, we adjusted the weight of each category in order to get results based on a sampling that reflects the 
firm size and industry distribution of the Flemish firm population. This means that in section 4.1, there is a correction for response in relation to industry and firm size (tables 1 and 2) and the response for the output figures. In section 4.2, there is also an extra correction based on the rate of coverage of the known clients (table 3). In section 4.3, the same correction is performed as in the previous section, but then with coefficients valid for the Antwerp agglomeration.

14. The equations are estimated by Tobit with both sides censored.

15. One question asked the respondents whether or not they belonged to a multinational.

16. Owing to the need for anonymity the firms are not known. It is likely that several firms will have the same suppliers/clients.

17. We define urban regions as the important and regional cities with their agglomeration. To define the municipalities of the agglomerations we used the definition in the Spatial Master plan of Flanders (Ministry of the Flemish Community 1997) - and of city regions (Vanderhaegen et al. 1996) (figure 1).

18. As explained, from this section on, urban means functional agglomeration. In the case of Brussels this implies that the agglomeration has a vaster territory than its institutional 19 municipalities (figure 1). This results in a penetration of the Brussels' functional agglomeration in Flanders and in Wallonia. This explains differences between figures on relationships with Brussels and Wallonia as compared with the previous section.

19. The average share of 'clients in Flanders' shows statistically significant differences $(p<0.01)$ for the different firm size categories.

20. We compared the sample of respondents that are located in the Antwerp agglomeration with the rest of the the companies that have answered the question about the market range of clients. The distribution across firm size categeories reveals that the distribution of firms in Antwerp across firm size categories is similar to the rest of Flanders (at least when the calculations are based upon the number of firms in each category). When the data are weighted by employment we get a somewhat different picture: firms in Antwerp are usually somewhat larger as the categories $>200$ employees are over-represented. The value for Cramer's coefficient is 0.113 (and statistically significant different from 0 ). This result is not surprising since urban areas are usually attractive for large companies.

We also compared the Antwerp agglomeration with other agglomerations. Again, the distribution across firm size categories is similar when calculations are based on the number of firms in each category. However, when the data are weighted with employment differences emerge (Cramer's coefficient raises to 0.056). Firms with 200 to 499 employess are over-represented; those with 50 to 199 employees are under-represented. There are substantial differences between Antwerp and the rest of Flanders concerning the distribution of the respondents across industries. Cramer's coefficient is 0.147 based on count data and 0.131 when the data are weighted by employment figures. The manufacturing and construction industries are under-represented in the Antwerp area and the business and financial services are clearly over-represented. Also TDL and wholsale are slightly over-represented when calculations are based on employment. Furthermore, there are also differences between Antwerp and other agglomerations in Flanders. Antwerp is the largest and most urbanized agglomeration. Cramer's coefficient is 0.130 based on count data and 0.115 when the data are weighted by employment figures. Here, too, industry and construction are under-represented and business services are over-represented. There are more financial services firms but they are on average a bit smaller than those in other agglomerations.

21. For this purpose we used generally available information sets (atlases and city database information). Locations within the radius of $10 \mathrm{~km}$ of the identified city are urban, the others are non-urban. Weighted with employment, $2.4 \%$ of total output and $4.5 \%$ of total input were not traceable in terms of urban/non-urban.

\section{References}

Aase, T. 1994 Symbolic space. Representations of space in geography and anthropology, Geografiska Annaler, 76B: 51-58.

Albrechts, L. and Lievois, G. 2004 The Flemish Diamond. Urban network in the making?, European Planning Studies, 12: 351-370

Albrechts, L., Van Den Broeck, J., Verachterd, K. and Coppens, T. 2003 Netwerken. Een theoretisch onderbouwd algemeen bruikbaar kader voor het verschijnsel netwerking in functie van de uitvoering van het ruimtelijk structuurplan Vlaanderen. Unpublished paper, Catholic University of Leuven, Leuven.

Appold, J. 1995 Agglomeration, interorganizational networks, and competitive performance in the U.S. metalworking sector, Economic Geography, 71: 27-54.

Asheim, B. 1996, Industrial districts as 'learning regions': a condition for prosperity, European Planning Studies, 4: 379-400.

Asheim, B. 1998 Learning regions as development coalitions: partnership as governance in European workfare states? Paper presented to the IGU Commission on Geography and Public Administration, Cambridge, 2-5 May. 
Asheim, B. 1999 Innovation, social capital and regional clusters: on the importance of co-operation, interactive learning and localized knowledge in learning economies, paper presented at the RSA International Conference on Regional Potentials in an Integrating Europe, Bilbao, 18-21 September.

Becattini, G. 1992 Le district marshallien, in Benko, B. and Lipietz, A. (eds), Les Régions qui gagnent. Districts et réseaux: les nouveaux paradigmes de la géographie économique (Paris: Presses Universitaires de France) pp. 35-55.

Beyers, W. and Lindahl, D. 1996 Explaining the demand for producer services: is cost-driven externalization the major factor?, Papers in Regional Science: The fournal of the RSAI, 75: 331-374

Bunnell, T. and Coe, N. 2001 Spaces and scales of innovation, Progress in Human Geography, 25: 569-589.

Cabus, P. 1999 De geografie van de ondernemingsstrategie. De toelevering aan de Belgische auto-industrie als onderlegger. Ph.D. dissertation, Catholic University of Leuven, Leuven.

Cabus, P. 2000 Modelling spatial relationships between Belgian car manufacturers and their suppliers using choremes, Tijdschrift voor Economische en sociale geografie, 91: 3-19.

Cabus, P. 2001 The meaning of local in a global economy, European Planning Studies, 9: 1011-1038.

Cabus, P. and Hess, M. 2000 Regional politics and economic patterns: glocalisation and the network enterprise, Belgeo, no. 1, 2, 3, 4: 79-101.

Cabus, P. and Vanhaverbeke, W. 2003a The economics of rural areas in the proximity of urban networks: evidence from Flanders, Tijdschrift voor Economische en Sociale Geografie, 94: 230-245.

Cabus, P. and Vanhaverbeke, W. 2003b The emerging network enterprise organizing space as networked territories, paper presented at the EGOS Conference: Organization Analysis Informing Social and Global Development, Copenhagen, April.

Cabus, P. and Vanhaverbeke, W. 2004 Ruimte en economie in Vlaanderen (Space and economy in Flanders) (Brussels-Ghent: Academia Press).

Cabus, P., Allaert, G. and Vanhaverbeke, W. 2001 De Ruimtelijk-Economische Hoofdstructuur van Vlaanderen. Concept in hoofdlijnen (The spatial economic main structure of Flanders. Concept in headlines) (Ghent: Academia Press).

Camagni, R. 1995 Global network and local milieu: towards a theory of economic space, in Conti, S., Malecki, E. and Oinas, P. (eds), The Industrial Enterprise and Its Environment: Spatial Perspectives (Aldershot: Avebury) pp. 195-214.

Castells, M. 1996 The Informational Age, Economy, Society and Culture, Vol. I, The Rise of the Network Society (Oxford: Blackwell).

Chapman, K. and Walker, D. 1987, 1991 Industrial Location (Oxford: Basil Blackwell).

Chardonnet, J. 1962 Géographie industrielle, Tome 1: Les sources d'énergie (Paris: Sirey).

Chardonnet, J. 1965 Géographie industrielle, Tome 2: L'industrie (Paris: Sirey).

DiGiovanna, S. 1996 Industrial districts and regional economic development: a regulation approach, Regional Studies, 30: 373-386.

Doz, Y. L., Santos, J. and Williamson, P. 2001 From Global to Metanational; How Companies Win in the Knowledge Economy (Boston, MA: Harvard Business School Press).

European Commission 1999 European Spatial Development Perspective. Towards Balanced and Sustainable Development of the Territory of the European Union (Luxembourg: European Commission).

Fujita, M., Krugman, P. and Venables, A. 1999 The Spatial Economy. Cities, Regions, and International Trade (Cambridge, MA \& London: MIT Press).

Gordon, I. R. and McCann, P. 2000 Industrial clusters: complexes, agglomeration and/or social networks?, Urban Studies, 37: 513-532

Gordon, I. R. and Murray, L. 1998 Community, locality and urban research, European Planning Studies, 6: $5-13$.

Graham, S. 1999 Global grids of glass: on global cities, telecommunications and planetary urban networks, Urban Studies, 36: 929-949.

Greene, W. H. 2000 Econometric Analysis, 4th edition (Englewood Cliffs, NJ: Prentice-Hall).

Guy, S., Graham, S. and Marvin, S. 1997 Splintering networks: cities and technical networks in 1990s Britain, Urban Studies, 34: 191-216.

Harrison, B. 1992 Industrial districts: old wine in new bottles?, Regional Studies, 26: 469-483.

Harvey, D. 1973 Social Fustice and the City (London: Edward Arnold).

Hassink, R. 1997 Localized industrial learning and innovation policies. Guest editorial, European Planning Studies, 5: 279-282.

Hinterhuber, H. H. and Levin, B. M. 1994 Strategic networks - the organization of the future, Long Range Planning, 27: 43-53.

Holland, S. 1976 Capital versus the Regions (London: Macmillan).

Houvenaghel, S. and Vanhaverbeke, W. (1997) Economische aspecten en relaties van omliggende gebieden met het stedelijk netwerk van de Vlaamse Ruit, Planologische Discussiedagen 1997 - thema 'Over Grenzen' 2: 355-364.

Illeris, S. 1994 Proximity between service producers and service users, Tijdschrift voor Economische en sociale geografie, 85: 294-302.

Kloosterman, R. C. and Musterd, S. 2001 Special issue: polycentric urban regions, Urban Studies, 38: 623-785. 
Krugman, P. 1991 Geography and Trade (Cambridge, MA: Leuven University Press \& MIT Press).

Lindahl, D. and Beyers, W. 1999 The creation of competitive advantage by producer service establishments, Economic Geography, 75: 1-20.

Maillat, D., Lecoq, B., Nemeti, F. and Phister, M. 1995 Technology district and innovation: the case of the Swiss Jura Arc, Regional Studies, 29: 251-263.

Malecki, E. and Poehling, R. 1999 Extroverts and introverts: small manufacturers and their information sources, Entrepreneurship \& Regional Development, 11: 247-268.

Malmberg, A. and Maskell, P. 1997 Towards an explanation of regional specialization and industry agglomeration, European Planning Studies, 5: 25-41.

Malmberg, A., Solvell, Ö. and Zander, I. 1996 Spatial clustering, local accumulation of knowledge and firm competitiveness, Geografiska Annaler, 78B: 85-97.

Markusen, A. 1997 Regional culture and regional politics as assets and handicaps for innovation, paper presented at the International Conference on Industry, Innovation and Territory, Lisbon, 20-22 March.

Martinelli, F. and Schoenberger, E. 1991 Oligopoly is alive and well: notes for a broader discussion of flexible accumulation, in Benko, G. and Dunford, M. (eds), Industrial Change and Regional Development: The Transformation of New Industrial Spaces (London: Belhaven Press) pp. 117-133.

Martinelli, F. and Schoenberger, E. 1992 Les oligopoles se portent bien, merci! Éléments de réflexion sur l'accumulation flexible, in Benko, B. and Lipietz, A. (eds), Les Régions qui gagnent. Districts et réseaux: les nouveaux paradigmes de la géographie économique (Paris: Presses Universitaires de France) pp. 164-188.

McDonald, J. F. and Moffitt, R. A. 1980 The uses of Tobit analysis, The Review of Economics and Statistics, 62: 318-321.

Miles, R. E. and Snow, C. C. 1995 The new network firm: a spherical structure built on a human investment philosophy, Organizational Dynamics, Spring: 5-18.

Ministerie van Economische Zaken (MINEZ) 1999 Nota Ruimtelijk Economisch beleid. Dynamiek in netwerken (Den Haag: MINEZ).

Ministry of the Flemish Community 1997 Spatial Master Plan Flanders (Brussels: Ministry of the Flemish Community).

Ministry of the Flemish Community 2003 Nadere uitwerking voor het Albertkanaal, Eindrapport (Brussels: Ministry of the Flemish Community).

Morgan, K. 1997 The learning region, Regional Studies, 30: 491-504.

Normann, R. 2001 Reframing Business: When the Map Changes the Landscape (Chichester: Wiley).

Ohmae, K. 1995/1996 The End of the Nation State: The Rise of Regional Economies (London: HarperCollins).

Oinas, P. and Malecki, E. 2002 The evolution of technologies in time and space: from national and regional to spatial innovation systems, International Regional Science Review, 25: 102-131.

Perroux, F. 1955 Note sur la notion de pôle de croissance, Economie Appliquée (Paris: ISMEA).

Piore, M. and Sabel, C. 1984 The Second Industrial Divide (New York: Basis Books).

Porter, M. 1990 The Competitive Advantage of Nations (London \& Basingstoke: Macmillan Press).

Porter, M. 1998 On Competition (Boston, MA: HBS Press).

Reid, N. 1995 Just-in-time inventory control and the economic integration of Japanese-owned manufacturing plants with the county, state and national economies of the United States, Regional Studies, 29: 345-355.

Richardson, T. and Jensen, O. 2000 Discourses of mobility and polycentric development: a contested view of European spatial planning, European Planning Studies, 8: 503-520.

Rusten, G. 2000 Geography of outsourcing: business service provisions among firms in Norway, Tijdschrift voor Economische en sociale geografie, 91: 122-134.

Sassen, S. 1991 The Global City, New York, London, Tokyo (Princeton, NJ: Princeton University Press).

Scott, A. 1988 Flexible production systems and regional development: the rise of new industrial spaces in North America and Western Europe, International Fournal of Urban and Regional Research, 2: 171-186.

Scott, A. 1990 Flexible production systems and regional development: the rise of new industrial spaces in North America and Western Europe, in Jakobsen, S., Networks and Regional Development (NordREFO) pp. 59-77.

Simmie, J. 2004 Innovation and clustering in the globalised international economy, Urban Studies, 41: 1095-1112.

Storper, M. 1995 The resurgence of regional economies, ten years later: the region as a nexus of untraded interdependencies, European Urban and Regional Studies, 2: 191-221.

Storper, M. 1997 The Regional World: Territorial Development in a Global Economy (New York: The Guilford Press).

Storper, M. 1999 The resurgence of regional economies, ten years later: the region as a nexus of untraded interdependencies, in Barnes, T. and Gertler, M. (eds), The New Industrial Geography. Regions, Regulations and Institutions (London \& New York: Routledge) pp. 23-53.

Storper, M. and Harrison, B. 1992 Flexibilité, hiérarchie et développement régional: les changements de structure des systèmes productifs industriels et leurs nouveaux modes de gouvernance dans les années 1990, in Benko, B. and Lipietz, A. (eds), Les Régions qui gagnent. Districts et réseaux: les nouveaux paradigmes de la géographie économique (Paris: Presses Universitaires de France) pp. 265-291. 
Suarez-Villa, L. and Rama, R. 1996 Outsourcing, R\&D and the pattern of intra-metropolitan location: the electronics manufacturing industries of Madrid, Urban Studies, 333: 1155-1197.

Swyngedouw, E. 1997 Excluding the other: the production of scale and scaled politics, in Lee, R. and Wills, J. (eds), Geographies of Economies (London: Arnold) pp. 167-176.

Taylor, P. J. 2004 World City Network. A Global Urban Analysis (London \& New York: Routledge).

Taylor, P. J. 2005 Inter-city relations within contemporary globalization, lecture on the colloquium marking the completion of Professor Peter J. Taylor's tenure of the International Francqui Chair, Ghent, 13-14 January.

Uitermark, J. 2002 Re-scaling, 'scale fragmentation' and the regulation of antagonistic relationships, Progress in Human Geography, 26: 743-765.

Vaessen, P. 1993 Small Business Growth in Contrasting Environments (Utrecht/Nijmegan: KNAG/ Faculteitbeleidswetenschappen, KU-Nijmegan).

Van der Haegen, H., Van Hecke, E. and Juchtmans, G. 1996 De Belgische Stadsgewesten, Statistische Studiën, 104: 42.

Van Dinteren, J., Bonamy, J., Sauviat, C. and Wood, P. 1994 Business services and networks, Tijdschrift voor Economische en sociale geografie, 85: 291-293.

Veltz, P. 1992 Hiérarchie et réseaux dans l'organisation de la production et du territoire, in Benko, B. and Lipietz, A. (eds), Les Régions qui gagnent. Districts et réseaux: les nouveaux paradigmes de la géographie économique (Paris: Presses Universitaires de France) pp. 293-313.

VROM 2001 Planologische kernbeslissingen Vijfde Nota Ruimtelijke Ordening (Tweede Kamer der StatenGeneraal, Vergaderjaar 2001-2002, 27: 578).

VROM 2004 Nota ruimte. Ruimte voor ontwikkeling (Note space. Space for development) (Den Haag: VROM). Weber, A. 1909 Über den Standort der Industrien (Tübingen: Mohr Verlag). 